\title{
Effect of Green Tea on Hepatic Cells Under the Influence of Inflammatory Conditions: In Vitro Study
}

\author{
${ }^{1,2}$ Ibrahim G. Saleh, ${ }^{1}$ Zulfiqar Ali, ${ }^{2}$ Farid M. Hamada, ${ }^{2}$ Mohamed F. Abd-Ellah, \\ ${ }^{1,3}$ Larry A. Walker, ${ }^{1,4,5}$ Ikhlas A. Khan and ${ }^{1}$ Mohammad K. Ashfaq \\ ${ }^{1}$ National Center for Natural Products Research, School of Pharmacy, \\ University of Mississippi, University, MS 38677, USA \\ ${ }^{2}$ Department of Pharmacology, Faculty of Pharmacy, Al-Azhar University, Nasr City, Cairo, Egypt \\ ${ }^{3,4}$ Department of Pharmacology, School of Pharmacy, University of Mississippi, University, MS 38677, USA \\ ${ }^{5}$ Department of Pharmacognosy, College of Pharmacy, King Saud University, Riyadh 11557, Saudi Arabia
}

Received 2013-11-25; Revised 2013-11-26; Accepted 2013-12-03

\begin{abstract}
The concern about safety of consumption of Green Tea (GT) supplements has become a scope of many studies. We and others have described earlier the effect of the administration of GT and its polyphenols on liver in a mouse model. In this study we aimed to investigate the effect of GT on HepG2 cells. HepG2 cells were treated with different concentrations of GT with and without presensitization with Lipopolysaccharide (LPS). The viability of cells did not change at low and moderate concentrations of GT, while at very high concentration; GT caused the viability of the cells to decrease. A decrease in the viability of presensitized cells was observed after exposure to moderate and high doses of GT. Also, OX.LDL, CXCL16, TNF $\alpha$, TGF $\beta$, RAR and RXR were found to be over-expressed in these cells, while this over-expression was not observed in the cells upon treatment with GT without LPS or upon treatment with LPS alone. These results indicate that GT even at high doses does not cause oxidative stress. However, under inflammatory stress conditions it may cause oxidative stress which in turn may lead to liver toxicity.
\end{abstract}

Keywords: Green Tea, Lipopolysaccharide, Hepatotoxicity, Inflammatory Conditions

\section{INTRODUCTION}

Green Tea (GT) contains polyphenols that are known to be strong antioxidants in vitro (Qin et al., 2013) and in vivo (Darvesh and Bishayee, 2013; Tsai et al., 2013; Zhong et al., 2012; Narotzki et al., 2013). Administration of GT polyphenol, epigallocatechin-3gallate (EGCG), to old rats has been shown to reduced oxidative stress as the EGCG-treated animals had decreased levels of lipid peroxidation and protein carbonylation, as well as increased levels of antioxidants and antioxidant enzymes in the liver, skeletal muscle and brain (Senthil et al., 2008; Srividhya et al., 2008). However, no effects were observed in young rats, suggesting that the antioxidant effects of GT polyphenols are only apparent in the presence of excessive oxidative stress. In a human study supplementation of the diets of healthy volunteers with tea catechins $\left(500 \mathrm{mg}\right.$ day $\left.^{-1}\right)$ for 4 weeks resulted in an $18 \%$ decrease in plasma oxidized lowdensity lipoprotein compared to the control (Inami et al., 2007). Similarly, supplementation of the diets of patients on hemodialysis with green tea catechins $\left(455 \mathrm{mg} \mathrm{day}^{-1}\right)$ for 3 months decreased plasma hydrogen peroxide, C-reactive protein and several pro-inflammatory cytokines compared to the controls (Hsu et al., 2007). In the human and experimental animal studies, the antioxidant activity of tea polyphenols has been shown to decrease oxidative DNA damage (Hakim et al., 2003; Frei and Higdon, 2003; Wang et al., 2003; Arimoto-Kobayashi et al., 2003). Conversely, tea catechins also become oxidized to generate ROS, which are readily observed in cell culture medium and lead to cell death (Singh et al., 2013;

Corresponding Author: Mohammad K. Ashfaq, National Center for Natural Products Research, School of Pharmacy, University of Mississippi, University, MS 38677, USA Tel: +1-662-915-1577, Fax: +1-662-915-7062 
Yang et al., 1998). The production of ROS such as $\mathrm{H}_{2} \mathrm{O}_{2}$ was shown earlier to cause cell death, not only for the cancer cells but also in the normal cells (Weisburg et al., 2004). In addition, there are case reports indicative of an association of high consumption of GT supplements with liver toxicity (Rohde et al., 2011; Isbrucker et al., 2006; Bonkovsky, 2006). The influence of GT polyphenols on liver is markedly augmented in the presence of Lipopolysaccharide (LPS) as a fever inducer as we have shown earlier (Saleh et al., 2013). Similarly, treatment with EGCG, decreased bile flow by $23 \%$ with a $70 \%$ reduction of biliary glutathione excretion in rats and caused a two-fold increase in plasma bile acids compared to the controls (Hirsova et al., 2013). These effects are probably caused by a pro-oxidant mechanism (Lambert et al., 2007).

In most of the studies cited above, experimental conditions were devoid of any contributing factor(s) that might play a role in GT toxicity. In many of the case reports of GT associated liver toxicity; other contributing factors like infection, fever or other inflammatory conditions were not taken into account or never investigated. In order to gain insight on the use of GT in stressful conditions, we presensitized HepG2 cells with LPS and examined the effect of GT on these cells.

\section{MATERIALS AND METHODS}

\subsection{Cells and Media}

HepG2 cells (ATCC, Manassas, VA. USA) were routinely grown using a DMEM medium containing glucose $4.5 \mathrm{~g} \mathrm{~L}^{-1}$, Sodium pyruvate $110 \mathrm{mg} \mathrm{L}^{-1}$, FBS $10 \%$ and Amikacin 1\%. Medium was changed every 3 days and sub cultured weekly. Cells were incubated at $37^{\circ} \mathrm{C}$ and $\mathrm{CO}_{2} 5 \%$ in humidified incubator.

\subsection{Treatments}

HepG2 Cells were cultured at the density of $1 \times 10^{4}$. One group of cultured cells was treated with Green Tea (GT) (in $1 \% \mathrm{DMSO}$ ) at concentrations of $100 \mu \mathrm{g} \mathrm{mL}^{-1}, 200 \mu \mathrm{g} \mathrm{mL}^{-1}$ and $500 \mu \mathrm{g} \mathrm{mL}^{-1}$. Another group of cultured cells was treated with $1 \%$ DMSO and served as a vehicle control. Lipopolysaccharide (LPS) at a concentration of $10 \mathrm{nM}$ (in PBS) was used for presensitization of one group of cultured HepG2 cells for $2 \mathrm{~h}$ before the treatment with GT. It was then washed out after the $2 \mathrm{~h}$.

\subsection{Cell Viability, Acridin Orange Assay:}

Procedure: Cells were cultured in 8 chambers Nunc slides (Thermo Fisher Scientific Inc. Waltham, MA. USA) for $24 \mathrm{~h}$ then were presensitized with LPS $2 \mathrm{~h}$, followed by treatment with GT for $24 \mathrm{~h}$ then washed using PBS pH 7.2.
The cells were then fixed using 4\% Paraformaldehyde (PFA) in PBS pH 7.2 for 15 min at room temperature. Cells were washed once with PBS for $5 \mathrm{~min}$, bathed in methanol for $5 \mathrm{~min}$ washed again with PBS $\mathrm{pH} 7.2$ and then incubated with $1 \mathrm{mg} \mathrm{mL}^{-1}$ RNAse solution for $30 \mathrm{~min}$ at room temperature to remove condensed and denatured DNA according to manufacturer's instructions (Immunochemistry Technologies LLC, Bloomington, MN. USA). After washing with PBS, the cells in each chamber were then exposed to $100 \mu \mathrm{L}$ of $0.1 \mathrm{~N} \mathrm{HCl}$ for 1 min and washed with PBS. A volume of a $100 \mu \mathrm{L}$ staining solution (composed of: $90 \mathrm{~mL}$ of citric acid $0.1 \mathrm{M}+10$ $\mathrm{mL} \mathrm{Na}_{2} \mathrm{HPO}_{4} 0.2 \mathrm{M}+1 \mathrm{~mL}$ of AO $6 \mu \mathrm{g} \mathrm{mL}^{-1}$ ) was added to each chamber. Cells were finally washed with PBS, the slides were air dried and cover slips were placed with fluoromount (aqueous mounting medium, Sigma-Aldrich, St. Louis, MO. USA). Slides were examined and imaged under Nikon fluorescent microscope (Model: Nikon eclipse 90i with a DS-U3 imaging system, Nikon Metrology, Inc., USA) for assessment of live and dead cells, using green and red channels.

\subsection{ICC and IF}

After appropriate treatments HepG2 cells in 8 chambers Nunc slides (Thermo Fisher Scientific Inc. Waltham, MA. USA), were fixed by adding $20 \mu \mathrm{L}$ of $4 \%$ paraformaldehyde (PFA) in PBS pH 7.2 for 15 min. Cells were washed once with PBS for $5 \mathrm{~min}$, followed by addition of $20 \mu \mathrm{L}$ of the blocking solution (composed of $1 \%$ BSA, $10 \%$ horse serum and $1 \%$ Triton X100 in PBS) to each chamber for $15 \mathrm{~min}$. After washing once with PBS for $5 \mathrm{~min}$, cells were incubated for $15 \mathrm{~min}$ at $37 \mathrm{C}$ with 10 $\mu \mathrm{L} /$ chamber of appropriate primary antibodies (Rabbit anti OX.LDL, CXCL16, RAR, RXR, TNF $\alpha$ and TGF $\beta$ ) (Abcam Cambridge, MA, USA). Cells were then washed once with PBS for $5 \mathrm{~min}$ and treated with $10 \mu \mathrm{L} /$ chamber of secondary antibody (TexRed) for $15 \mathrm{~min}$ at $37^{\circ} \mathrm{C}$. Cells were washed once with PBS for $5 \mathrm{~min}$ at room temperature. For nuclear staining, a $20 \mu \mathrm{L}$ of DAPI was added to each chamber and the slide was incubated-for $5 \mathrm{~min}$ at $37^{\circ} \mathrm{C}$. Slides were then washed once with PBS, air dried, were mounted with cover slip. Cells were examined and imaged using Nikon fluorescence microscope (Model: Nikon eclipse 90i with a DS-U3 imaging system, Nikon Metrology, Inc. USA) under blue and red channels.

\section{RESULTS}

\subsection{OX.LDL}

The results in Fig. 1 show that Green Tea (GT) alone did not significantly increase OX.LDL in HepG2 cells even at the high concentration of $500 \mu \mathrm{g}$ 
$\mathrm{mL}^{-1}$ compared to control. Presensitization of HepG2 cells with $10 \mathrm{nM}$ of Lipopolysaccaride (LPS) caused GT $\left(200\right.$ and $\left.500 \mu \mathrm{g} \mathrm{mL} \mathrm{mL}^{-1}\right)$ to increase OX.LDL expression by 25 and 35 folds, respectively compared to control. However, no such effect was observed with $\mathrm{GT}$ at $100 \mu \mathrm{g} \mathrm{mL}^{-1}$ in presensitized cells.

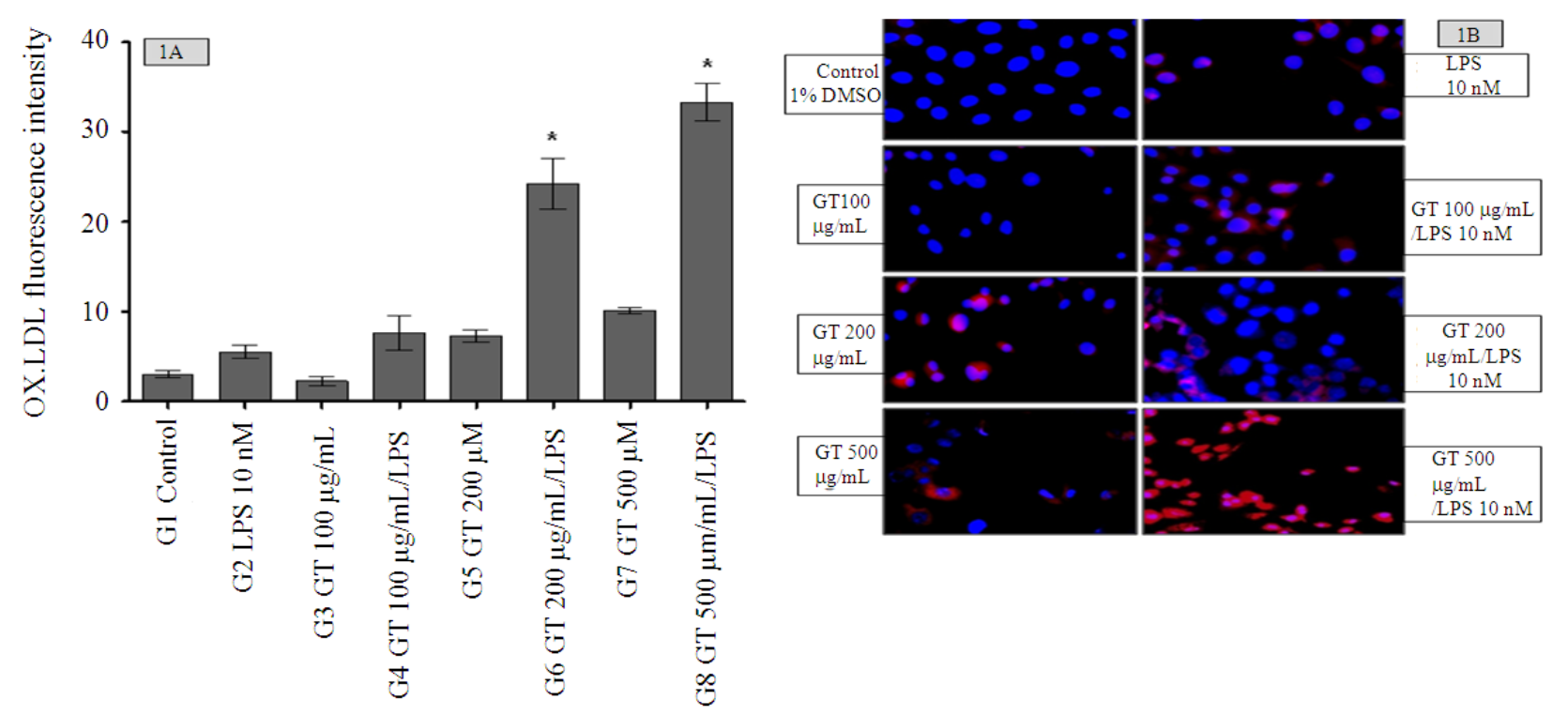

Fig. 1. (A, B): Expression of OX.LDL in HepG2 cells after treatment with different concentrations of GT with or without presensitization with LPS. Blue $(\mathrm{DAPI})=$ Nucleus, Red $($ TexRed $)=$ OX.LDL. 100X magnification power
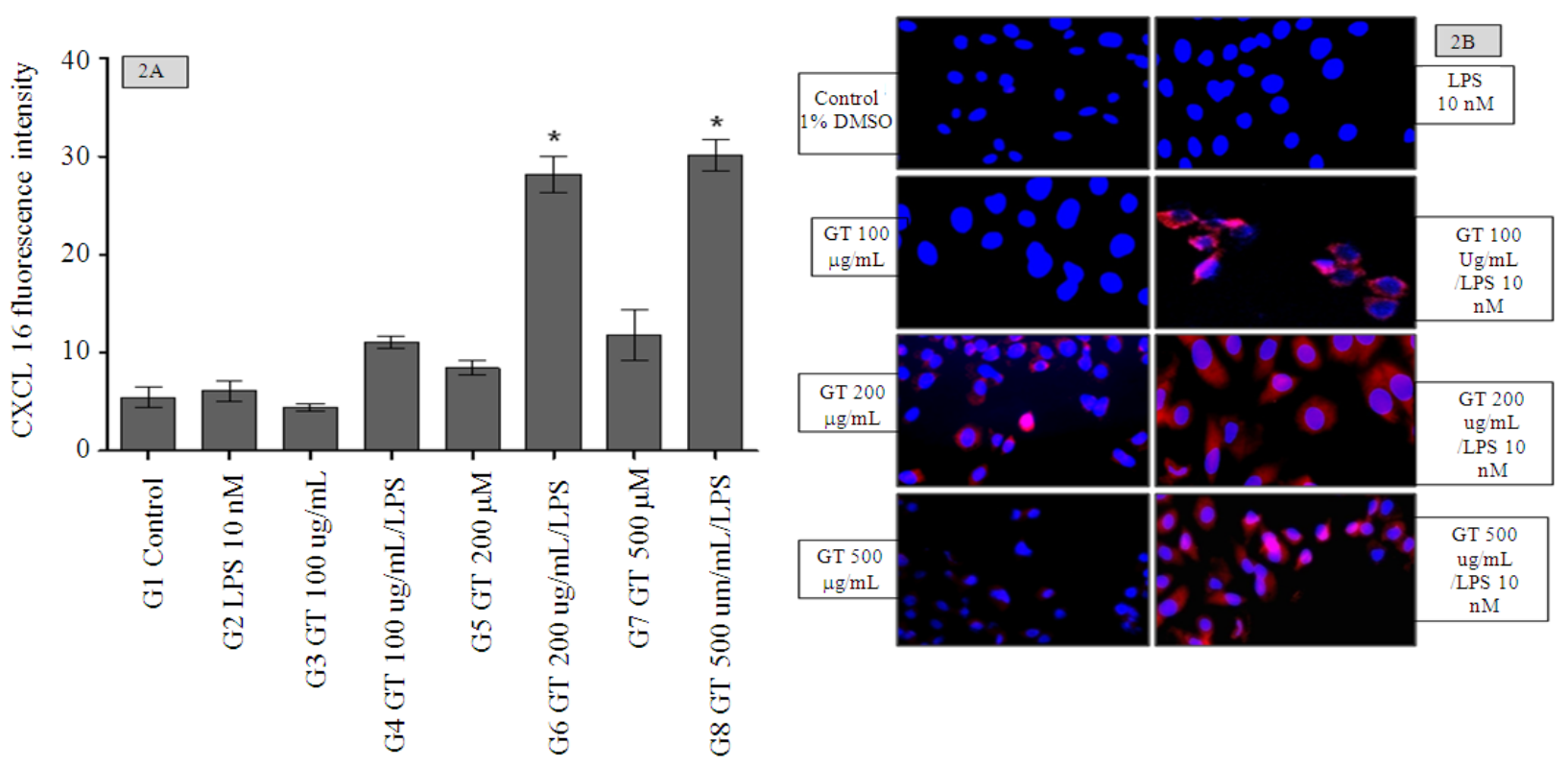

Fig. 2. (A, B): Expression of CXCL16 in HepG2 cells after treatment with different concentrations of GT with or without presensitization with LPS. Blue $(\mathrm{DAPI})=$ Nucleus, Red $($ TexRed $)=$ CXCL16. 100X magnification power 


\subsection{CXCL16}

The results in Fig. 2 show that GT alone did not significantly increase CXCL16 in HepG2 cells even at the high concentration of $500 \mu \mathrm{g} \mathrm{mL} \mathrm{m}^{-1}$ compared to control. Presensitization of HepG2 cells caused GT (200 and $500 \mu \mathrm{g} \mathrm{mL} \mathrm{m}^{-1}$ ) to increase CXCL16 expression by 5 and 6 folds, respectively compared to control. However, no such effect was observed with GT at $100 \mu \mathrm{g} \mathrm{mL}^{-1}$ in presensitized cells.

\subsection{RAR}

The results in Fig. 3 show that even high concentration of $500 \mu \mathrm{g} \mathrm{mL}^{-1}$ of GT alone did not significantly increase the expression of RAR compared to control.

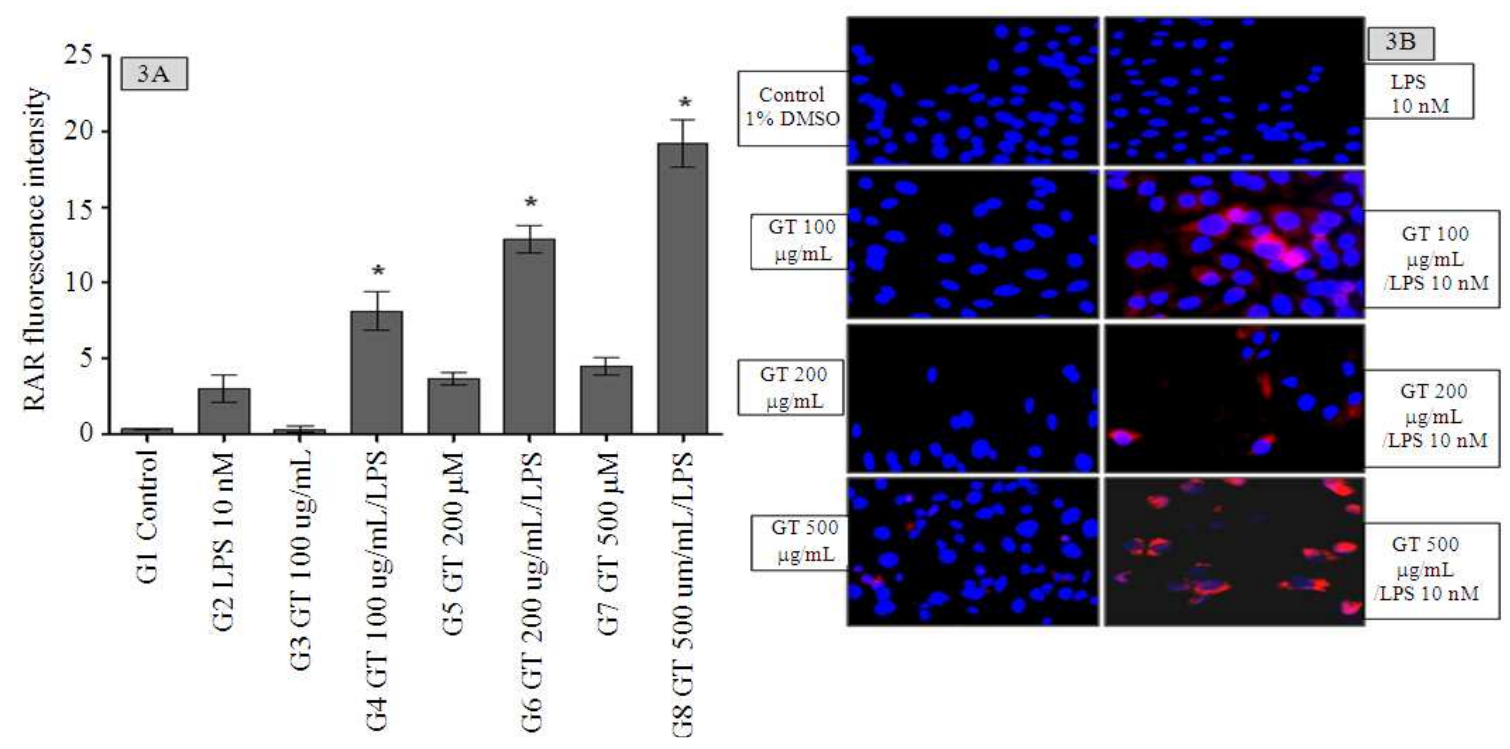

Fig. 3. (A, B): Expression of RAR in HepG2 cells after treatment with different concentrations of GT with or without presensitization with LPS. Blue $($ DAPI $)=$ Nucleus, Red $($ TexRed $)=$ RAR. 100X magnification power

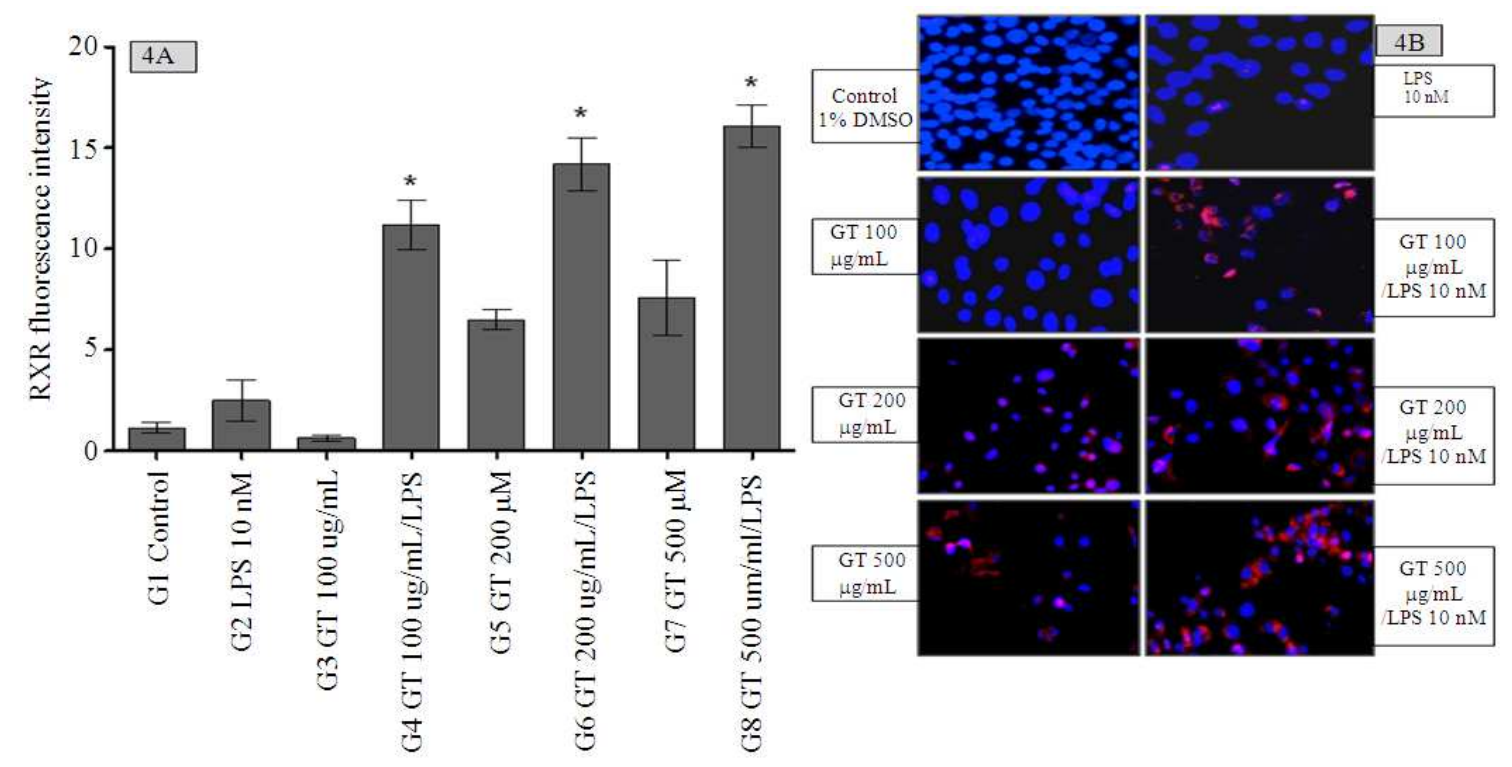

Fig. 4. (A, B): Expression of RAR $\alpha$ in HepG2 cells after treatment with different concentrations of GT with or without presensitization with LPS. Blue $(\mathrm{DAPI})=$ Nucleus, Red $($ TexRed $)=\operatorname{RXR} \alpha .100 \mathrm{X}$ magnification power 
Presensitization of HepG2 cells caused GT (100, 200 and $500 \mu \mathrm{g} \mathrm{mL}^{-1}$ ) to increase RAR expression by 25,40 and 60 folds, respectively compared to control.

\section{4. $\operatorname{RXR\alpha }$}

The results in Fig. 4 show that even high concentration of $500 \mu \mathrm{g} \mathrm{mL}^{-1}$ of GT alone did not significantly increase the expression of $\operatorname{RXR} \alpha$ compared to control.
Presensitization of HepG2 cells caused GT (100, 200 and $500 \mu \mathrm{g} \mathrm{mL}^{-1}$ ) to increase RXR $\alpha$ expression by 11,14 and 16 folds, respectively compared to control.

\subsection{TNF $\alpha$}

The results in Fig. 5 show that even high concentration of $500 \mu \mathrm{g} \mathrm{mL} \mathrm{m}^{-1}$ of GT alone did not significantly increase the expression of TNF $\alpha$ compared to control.

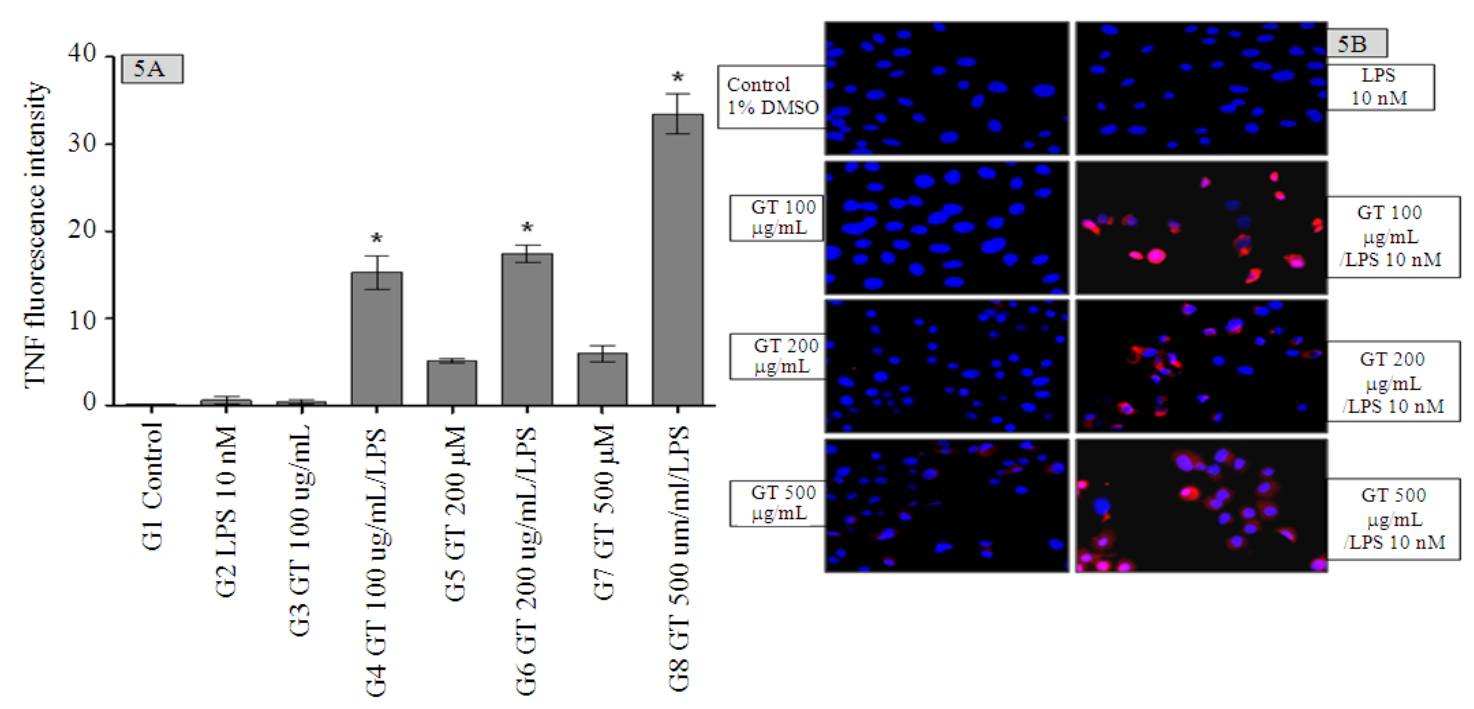

Fig. 5. (A, B): Expression of TNF $\alpha$ in HepG2 cells after treatment with different concentrations of GT with or without presensitization with LPS. Blue $(\mathrm{DAPI})=$ Nucleus, Red $($ TexRed $)=$ TNF $\alpha$. 100X magnification power

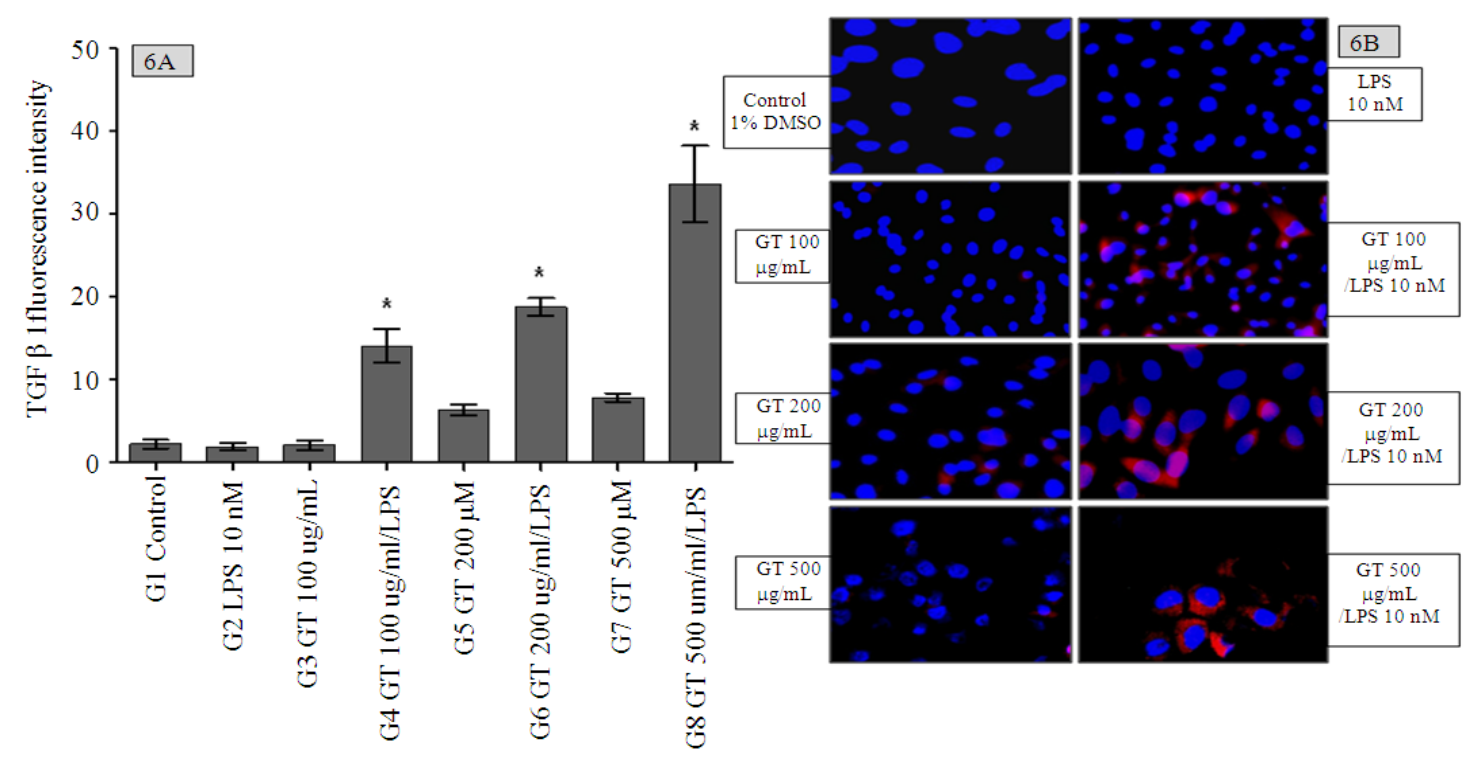

Fig. 6. (A, B): Expression of TGF $\beta 1$ in HepG2 cells after treatment with different concentrations of GT with or without presensitization with LPS. Blue $(\mathrm{DAPI})=$ Nucleus, Red $($ TexRed $)=\mathrm{TNF} \alpha .100 \mathrm{X}$ magnification power 


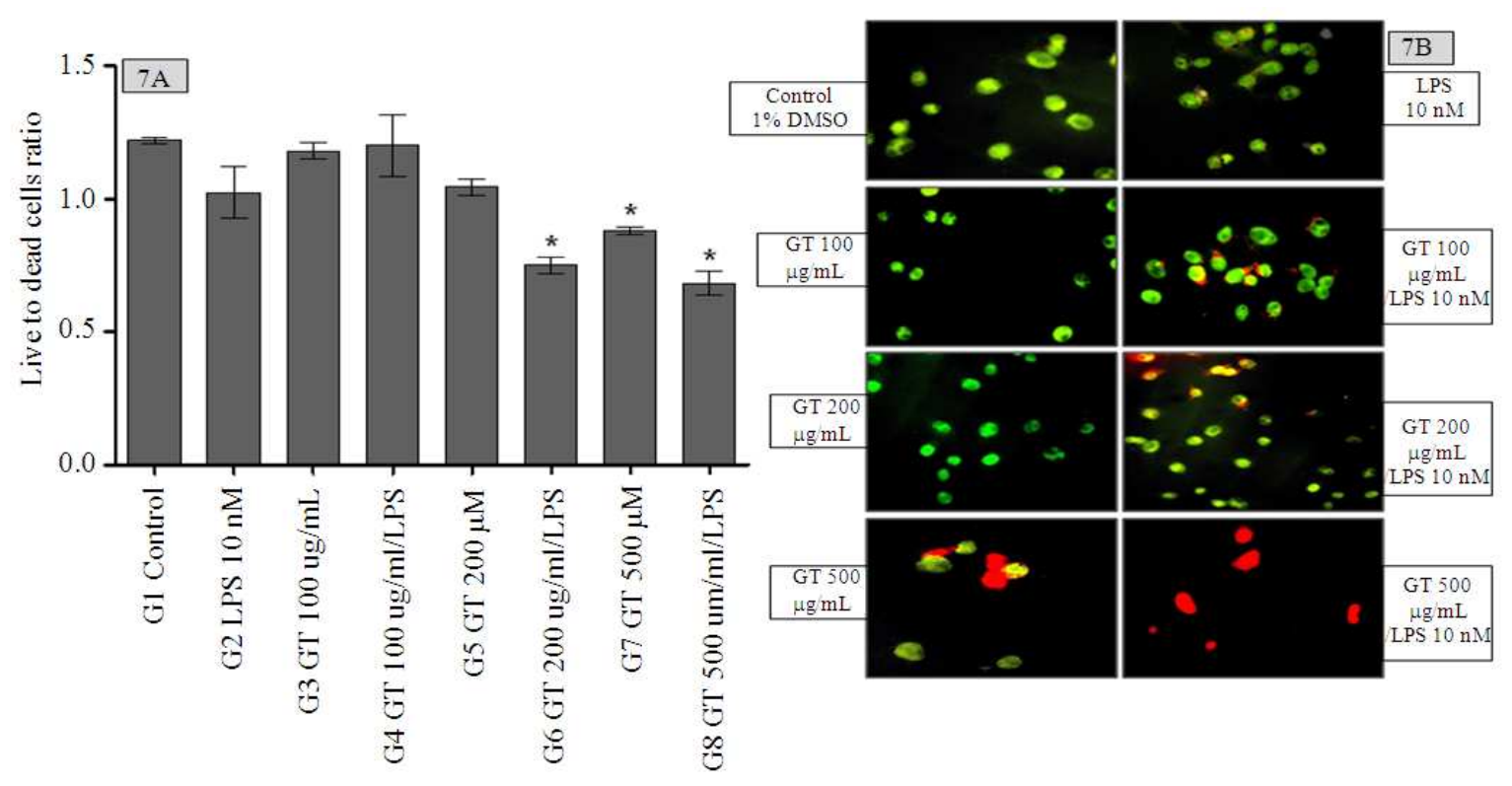

Fig. 7. (A, B): Determination of the viability of HepG2 cells using Acridin Orange stain, after treatment with different concentrations of GT and/or LPS. Green = Viable, Yellow- Red $=$ Dead. 100X magnification power

Presensitization of HepG2 cells caused GT (100, 200 and $500 \mu \mathrm{g} \mathrm{mL}^{-1}$ ) to increase TNF $\alpha$ expression by 90,100 and 200 folds, respectively compared to control.

\subsection{TGF B1}

The results in Fig. 6 show that even high concentration of 500 of GT alone did not significantly increase the expression of TGF $\beta 1$ compared to control. Presensitization of HepG2 cells caused GT (100, 200 and $500 \mu \mathrm{g} \mathrm{mL}^{-1}$ ) to increase TGF $\beta 1$ expression by 6,9 and 15 folds, respectively compared to control.

\subsection{Live to Dead Cells Ratio}

Treatment of HepG2 cells with a low concentration of $100 \mu \mathrm{g} \mathrm{mL} \mathrm{m}^{-1}$ of GT and moderate concentration of 200 of GT did not show any significant decrese in the live to dead cells ratio compared to control. A high concentration of $500 \mu \mathrm{g} \mathrm{mL} \mathrm{m}^{-1}$ of GT significantly decreased the live to dead cells ratio compared to control. This ratio was further decreased in the cells that were presensitized with $10 \mathrm{nM}$ of LPS (Fig. 7).

\section{DISCUSSION}

In a previous in vivo study, we subtoxic dose of LPS augmented liver toxicity of EGCG (Saleh et al., 2013). In the current study, several parameters, associated with oxidative stress and inflammation, were assessed to clarify the pattern of toxicity of GT on liver cells under the influence of LPS. Oxidized Low Density Lipoprotein (OX.LDL) initiates intracellular oxidative stress by means of its lipid peroxidation products leading to the activation of the tumor suppressor gene p53 resulting in cell cycle arrest, necrosis or apoptosis (Maziere et al., 2000). Also, CXCL16 has been reported to be expressed in a variety of inflammatory diseases (Oh et al., 2009). Besides, it acts as a scavenger receptor for OX.LDL (Gutwein et al., 2009). In the current study, GT alone showed no effect on the expression of OX.LDL or CXCL16 even at the high concentration of $500 \mu \mathrm{g} \mathrm{mL}^{-1}$. Similarly, Presensitization of HepG2 cells with LPS alone did not overly express OX.LDL or CXCL16. While exposure of LPS-presensitized cells to GT at moderate and high concentrations (200 and $500 \mu \mathrm{g}$ $\mathrm{mL}^{-1}$ ) significantly increased the expression of OX.LDL and CXCL16; the low concentration of GT (100 $\mu \mathrm{g}$ $\mathrm{mL}^{-1}$ ), however, did not show this effect and may have exerted its antioxidant effect at this concentration. These results clearly suggest that GT alone is not implicated in causing oxidative stress. However, under inflammatory conditions it can cause oxidative stress. These results demonstrate that the effect is not solely related to LPS, but it gives a hint about the possibility that LPS may cause GT to exhibit a pro-oxidant effect. 
Vitamin A derivative Retinoic Acid (RA) is an important regulator of mammalian adiposity and lipid metabolism, primarily acting at the gene expression level through nuclear receptors of the RA Receptor (RAR) and Retinoid X Receptor (RXR) subfamilies (Amengual et al., 2012). RAR and RXR are nuclear receptors expressed in almost every cellular type and tissue (Mahajna et al., 1997; Lehmann et al., 1992; Kliewer et al., 1992). Three isoforms of RXR have been found in human, named $\operatorname{RXR} \alpha, \beta$ and $\gamma$, being the $\alpha$-isoform the most abundant in the liver (Mangelsdorf et al., 1992; Heyman et al., 1992). These nuclear receptors are important regulators of cell proliferation and differentiation (Abdel-Bakky et al., 2011). Unique among the other nuclear receptors, $\mathrm{RXR} \alpha$ plays a major role in regulating bile acid, cholesterol, fatty acid, steroid and xenobiotic metabolism and homeostasis (Abdel-Bakky et al., 2011). Hepatic Stellate Cells (HSC) have the ability to store retinoids in normal conditions. In liver injury, HSCs have been shown to release retinoic acid in the form of lipid droplets, thus up regulation of retinoid receptors (RAR and RXR) occurs (Minato et al., 1983). HepG2 cells tend to behave as HSCs in their ability to store retinoids in normal conditions (Lenich and Ross, 1987) and may release them upon cell injury. In the current study, GT showed no effect on the expression of RAR and RXR $\alpha$ even at the high concentration of $500 \mu \mathrm{g} \mathrm{mL} \mathrm{m}^{-1}$. Also, pre-sensitization of cells with LPS did not exhibit RAR or RXR over expression. However, exposure of LPS-presensitized significantly increased the expression of RAR and RXR even at a low concentration of $100 \mu \mathrm{g} \mathrm{mL} \mathrm{m}^{-1}$ of GT. These results add credence to those of OX.LDL and CXCL16 in confirming the safety of GT alone and the possibility of GT to exhibit a pro-oxidant activity in the presence of a predisposing factor such as LPS and thus could result in hepatocellular injury.

Tumor Necrosis Factor alpha (TNF $\alpha$ ) is used clinically as a biomarker for hepatic cell fibrosis (Bahcecioglu et al., 2004) and nonalcoholic fatty liver disease (Ma et al., 2013). It also increases in the stages of angiogenesis following inflammatory liver cirrhosis (Hammam et al., 2013). Similarly, transforming growth factor beta1 (TGF $\beta 1$ ) is a multifunctional cytokine of a great pathophysiologic impact on various types of liver diseases (Gressner et al., 2002). It is more relevant in cases of liver fibrosis, regeneration, metastasis of hepatocellular carcinoma and the development of autoimmune liver diseases (Kanzler et al., 1999). The current study showed that treatment with GT alone did not cause a shift in the expression of TNF $\alpha$ or TGF $\beta$ even at a high concentration of $500 \mu \mathrm{g} \mathrm{mL}^{-1}$. However, exposure of LPS-presensitized cells to GT significantly increased the expression of TNF $\alpha$ as well as TGF $\beta$ even at a low concentration of $100 \mu \mathrm{g} \mathrm{mL}^{-1}$. These results further validate that under normal conditions, GT by itself has no toxic effect on liver cells even at high concentrations. But with presensitization of liver cells with LPS, treatment with GT may show toxic effects.

The data of HepG2 cell viability in the current study confirms almost all the previously discussed results. It shows that GT does not shift the live to dead cells ratio compared to control except at the high concentration of $500 \mu \mathrm{g} \mathrm{mL} \mathrm{m}^{-1}$. The later result although does not support the other results, but it cannot be very indicative because of the very high concentration of $500 \mu \mathrm{g} \mathrm{mL} \mathrm{mL}^{-1}$ compared to human doses. The more reliable indicative concentrations are the low and moderate doses of 100 and $200 \mu \mathrm{g} \mathrm{mL}^{-1}$, respectively. The treatment of the presensitized cells with GT at a low concentration of $100 \mu \mathrm{g} \mathrm{mL} \mathrm{m}^{-1}$ did not show any shift in the live to dead cells ratio, the issue that confirms the ability of GT to act as an antioxidant at low concentrations. Presensitization of HepG2 cells with LPS caused moderate dose of $200 \mu \mathrm{g} \mathrm{mL} \mathrm{m}^{-1}$ of GT to show a significant decrease of the live to dead cells ratio compared to control, the issue that confirms the role of LPS as a predisposing factor in shifting the antioxidant effect of GT to a pro-oxidant one.

\section{CONCLUSION}

It is concluded from the current study that GT does not show toxicity towards liver cells even at high concentrations. However, predisposing conditions such as inflammatory stress can change this scenario. The relatively safe dose of GT under such circumstances can cause liver cell toxicity. In other words, the antioxidant effect of GT can change into pro-oxidant effect under such predisposing conditions. It is important here to recommend that the pre-clinical safety assessment of new products including the natural supplements should be carried out in healthy and health compromised conditions. It will be of interest to study the individual components of GT extract in vitro and in vivo. Extrapolation of in vitro data for in vivo studies is difficult. However, the current study does provide a platform for future in vivo studies.

\section{ACKNOWLEDGMENT}

This research is supported in part by "Science Based Authentication of Dietary Supplements" funded by the Food and Drug Administration grant number 1U01FD004246. 


\subsection{Conflict of Interest}

All authors state that there is no conflict of interest with the work done in this study.

\section{REFERENCES}

Abdel-Bakky, M.S., M.A. Hammad, L.A.Walker and M.K. Ashfaq, 2011. Tissue factor dependent liver injury causes release of retinoid receptors (RXRalpha and RAR-alpha) as lipid droplets. Biochem. Biophyioogy Res. Commun., 410: 146-151. DOI: 10.1016/j.bbrc.2011.05.127

Amengual, J., P. Petrov, M.L. Bonet, J. Ribot and A. Palou, 2012. Induction of carnitine palmitoyl transferase 1 and fatty acid oxidation by retinoic acid in HepG2 cells. Int. J. Biochem. Cell Biol., 44: 2019-2027. DOI: 10.1016/j.biocel.2012.07.026

Arimoto-Kobayashi, S., N. Inada, Y. Sato, C. Sugiyama and K. Okamoto et al., 2003. Inhibitory effects of ()epigallocatechin gallate on the mutation, DNA strand cleavage and DNA adduct formation by heterocyclic amines. J. Agric. Food Chem., 51: 5150-5153. DOI: 10.1021/jf0302761

Bahcecioglu, I.H., M. Yalniz, H. Ataseven, N. Bulbuller and M. Kececi et al., 2004. TNF-alpha and leptin in experimental liver fibrosis models induced by carbon tetrachloride and by common bile duct ligation. Cell Biochem. Funct., 22: 359-363. DOI: $10.1002 / \mathrm{cbf} .1114$

Bonkovsky, H.L., 2006. Hepatotoxicity associated with supplements containing Chinese green tea (Camellia sinensis). Ann. Int. Med., 144: 68-71. DOI: 10.7326/0003-4819-144-1-200601030-00020

Darvesh, A.S. and A. Bishayee, 2013. Chemopreventive and therapeutic potential of tea polyphenols in hepatocellular cancer. Nutr. Cancer, 65: 329-344. DOI: $10.1080 / 01635581.2013 .767367$

Frei, B. and J.V. Higdon, 2003. Antioxidant activity of tea polyphenols in vivo: Evidence from animal studies. J. Nutr., 133: 3275S-3284S. PMID: 14519826

Gressner, A.M., R. Weiskirchen, K. Breitkopf and S. Dooley, 2002. Roles of TGF-beta in hepatic fibrosis. Front Biosci., 7: d793-d807. PMID: 11897555

Gutwein, P., M.S. Abdel-Bakky, K. Doberstein, A. Schramme and J. Beckmann et al., 2009. CXCL16 and oxLDL are induced in the onset of diabetic nephropathy. J. Cellular Molecular Med., 13: 38093825. DOI: $10.1111 /$ j.1582-4934.2009.00761.x
Hakim, I.A., R.B. Harris, S. Brown, H.H. Chow and S. Wiseman et al., 2003. Effect of increased tea consumption on oxidative DNA damage among smokers: A randomized controlled study. J. Nutr., 133: 3303S-3309S. PMID: 14519830

Hammam, O., O. Mahmoud, M. Zahran, A. Sayed and R. Salama et al., 2013. A Possible Role for TNF-alpha in coordinating inflammation and angiogenesis in chronic liver disease and hepatocellular carcinoma. Gastrointestinal Cancer Res., 6: 107-114.

Heyman, R.A., D.J. Mangelsdorf, J.A. Dyck, R.B. Stein and G. Eichele et al., 1992. 9-cis retinoic acid is a high affinity ligand for the retinoid $\mathrm{X}$ receptor. Cell, 68: 397-406. DOI: 10.1016/0092-8674(92)90479-V.

Hirsova, P., G. Karlasova, E. Dolezelova, J. Cermanova and M. Zagorova et al., 2013. Cholestatic effect of epigallocatechin Gallate in rats is mediated via decreased expression of Mrp2. Toxicology, 303: 915. DOI: 10.1016/j.tox.2012.10.018

Hsu, S.P., M.S. Wu, C.C. Yang, K.C. Huang and S.Y. Liou et al., 2007. Chronic green tea extract supplementation reduces hemodialysis-enhanced production of hydrogen peroxide and hypochlorous acid, atherosclerotic factors and proinflammatory cytokines. Am. J. Clin. Nutr., 86: 1539-1547. PMID: 17991670

Inami, S., M. Takano, M. Yamamoto, D. Murakami and K. Tajika et al., 2007. Tea catechin consumption reduces circulating oxidized low-density lipoprotein. Int. Heart J., 48: 725-732. DOI: 10.1536/ihj.48.725

Isbrucker, R.A., J.A. Edwards, E. Wolz, A. Davidovich and J. Bausch, 2006. Safety studies on Epigallocatechin Gallate (EGCG) preparations. Part 2: dermal, acute and short-term toxicity studies. Food Chem. Toxicol., 44: 636-650. DOI: 10.1016/j.fct.2005.11.003

Kanzler, S., A.W. Lohse, A. Keil, J. Henninger and H.P. Dienes et al., 1999. TGF-betal in liver fibrosis: An inducible transgenic mouse model to study liver fibrogenesis. Am. J. Physiol., 276: G1059-G1068. PMID: 10198351

Kliewer, S.A., K. Umesono, D.J. Mangelsdorf and R.M. Evans, 1992. Retinoid X receptor interacts with nuclear receptors in retinoic acid, thyroid hormone and vitamin D3 signalling. Nature, 355: 446-449. DOI: $10.1038 / 355446 \mathrm{a} 0$

Lambert, J.D., S. Sang and C.S. Yang, 2007. Possible controversy over dietary polyphenols: Benefits vs risks. Chem. Res. Toxicol., 20: 583-585. DOI: $10.1021 / \mathrm{tx} 7000515$ 
Lehmann, J.M., L. Jong, A. Fanjul, J.F. Cameron and X.P. Lu et al., 1992. Retinoids selective for retinoid $\mathrm{X}$ receptor response pathways. Science, 258: 19441946. DOI: $10.1126 /$ science. 1335166

Lenich, C.M. and A.C. Ross, 1987. Chylomicron remnant-vitamin a metabolism by the human hepatoma cell line HepG2. J. Lipid Res., 28: 183194. PMID: 3033118

Ma, Y.Y., L. Li, C.H. Yu, Z. Shen and L.H. Chen et al., 2013. Effects of probiotics on nonalcoholic fatty liver disease: A meta-analysis. World J. Gastroenterol., 19: 6911-6918. DOI: 10.3748/wjg.v19.i40.6911

Mahajna, J., B. Shi and A. Bruskin, 1997. A four-aminoacid insertion in the ligand-binding domain inactivates hRXRbeta and renders dominant negative activity. DNA Cell Biol., 16: 463-476. PMID: 9150434

Mangelsdorf, D.J., U. Borgmeyer, R.A. Heyman, J.Y. Zhou and E.S. Ong et al., 1992. Characterization of three RXR genes that mediate the action of 9-cis retinoic acid. Genes Dev., 6: 329-344. DOI: 10.1101/gad.6.3.329

Maziere, C., A. Meignotte, F. Dantin, M.A. Conte and J.C. Maziere, 2000. Oxidized LDL induces an oxidative stress and activates the tumor suppressor p53 in MRC5 human fibroblasts. Biochem. Biophys. Res. Commun., 276: 718-723. DOI: $10.1006 /$ bbrc. 2000.3528

Minato, Y., Y. Hasumura and J. Takeuchi, 1983. The role of fat-storing cells in Disse space fibrogenesis in alcoholic liver disease. Hepatology, 3: 559-566. PMID: 6862368

Narotzki, B., Y. Levy, D. Aizenbud and A.Z. Reznick, 2013. Green tea and its major polyphenol EGCG increase the activity of oral peroxidases. Adv. Exp. Med. Biol., 756: 99-104. DOI: 10.1007/978-94-0074549-0 13

Oh, S.T., A. Schramme, W. Tilgen, P. Gutwein and J. Reichrath, 2009. Overexpression of CXCL16 in lesional psoriatic skin. Dermatoendocrinology, 1: 114-118. DOI: $10.4161 /$ derm.1.2.7750

Qin, Y., X.W. Guo, L. Li, H.W. Wang and W. Kim, 2013. The antioxidant property of chitosan green tea polyphenols complex induces transglutaminase activation in wound healing. J. Med. Food, 16: 487498. DOI: $10.1089 /$ jmf.2012.2623

Rohde, J., C. Jacobsen and H. Kromann-Andersen, 2011. Toxic hepatitis triggered by green tea. Ugeskrift Laeger, 173: 205-206. PMID: 21241631
Saleh, I.G., Z. Ali, N. Abe, F.D. Wilson and F.M. Hamada et al., 2013. Effect of green tea and its polyphenols on mouse liver. Fitoterapia, 9: 151-159. DOI: 10.1016/j.fitote.2013.07.014

Senthil, K., K. Arulmathi, R. Srividhya and P. Kalaiselvi, 2008. Repletion of antioxidant status by EGCG and retardation of oxidative damage induced macromolecular anomalies in aged rats. Exp. Gerontol., 43: 176-183. DOI: 10.1016/j.exger.2007.10.017

Singh, M., K. Bhui, R. Singh and Y. Shukla, 2013. Tea polyphenols enhance cisplatin chemosensitivity in cervical cancer cells via induction of apoptosis. Life Sci., 93: 7-16. DOI: 10.1016/j.1fs.2013.02.001

Srividhya, R., V. Jyothilakshmi, K. Arulmathi, V. Senthilkumaran and P. Kalaiselvi, 2008. Attenuation of senescence-induced oxidative exacerbations in aged rat brain by (-)-epigallocatechin-3-gallate. Int. J. Dev. Neurosci., 26: 217-223. DOI: 10.1016/j.ijdevneu.2007.12.003

Tsai, C.F., Y.W. Hsu, H.C. Ting, C.F. Huang and C.C. Yen, 2013. The in vivo antioxidant and antifibrotic properties of green tea (Camellia sinensis, Theaceae). Food Chem., 136: 1337-1344. DOI: 10.1016/j.foodchem.2012.09.063

Wang, Z., L. Zeng, Y. Xiao, S. Lu and X. Gao, 2003. Protective effects of green tea on mice with the irradiating damage induced by gamma-ray. Sichuan. Da Xue Xue Bao Yi Xue Ban, 34: 303-305. PMID: 1294772

Weisburg, J.H., D.B. Weissman, T. Sedaghat and H. Babich, 2004. In vitro cytotoxicity of epigallocatechin gallate and tea extracts to cancerous and normal cells from the human oral cavity. Basic Clin. Pharmacol. Toxicol., 95: 191200. DOI: $10.1111 /$ j.1742-7843.2004.pto_950407.x

Yang, G.Y., J. Liao, K. Kim, E.J. Yurkow and C.S. Yang, 1998. Inhibition of growth and induction of apoptosis in human cancer cell lines by tea polyphenols. Carcinogenesis, 19: 611-616. DOI: 10.1093/carcin/19.4.611

Zhong, Y., Y.S. Chiou, M.H. Pan and F. Shahidi, 2012. Anti-inflammatory activity of lipophilic Epigallocatechin Gallate (EGCG) derivatives in LPS-stimulated murine macrophages. Food Chem., 134: 742-748. DOI: 10.1016/j.foodchem.2012.02.17 